\title{
Retraction Note: Japanese vocabulary translation of seawater desalination environmental impact and trade based on geoinformatics
}

\section{Dan $\mathrm{Li}^{1}$}

Published online: 12 November 2021

(c) Saudi Society for Geosciences 2021

Retraction Note: Arabian Journal of Geosciences (2021) 14: 1387

https://doi.org/10.1007/s12517-021-07640-z

The Editor-in-Chief and the Publisher have retracted this article because the content of this article is nonsensical. The peer review process was not carried out in accordance with the Publisher's peer review policy. The author has not responded to correspondence regarding this retraction.

Publisher's note Springer Nature remains neutral with regard to jurisdictional claims in published maps and institutional affiliations.

The original article can be found online at https://doi.org/10.1007/ s12517-021-07640-z.

Dan Li

lidan860906@163.com

1 School of Foreign Studies, Yangtze University, JingZhou 434023, Hubei, China 